\title{
Paleomagnetic evidence for Miocene transtensional deformations at the eastern margin of the Japan Sea
}

\author{
Atsushi Yamaji, Hiroshi Momose*, and Masayuki Torii** \\ Division of Earth and Planetary Sciences, Kyoto University, Kyoto 606-8502, Japan \\ (Received July 30, 1997; Revised October 28, 1998; Accepted November 18, 1998)
}

\begin{abstract}
The opening of the Japan Sea backarc basin accompanied dextral, transtensional deformations in the NE Japan arc. To understand the intra-arc deformation we have studied paleomagnetism in the Uetsu area, NE Japan. Among the samples collected at 70 sites for paleomagnetic measurement reliable directions were obtained at 38 ones. About half of the sites yielded clockwise and the others show opposite declinations. Our data indicate that the northern Uetsu area rotated counterclockwise as a single block, whereas the southern Uetsu area was broken into a number of blocks that was rotated clockwise by the dextral transtension along the Nihonkoku-Miomote Line. Not only the Uetsu area but the entire eastern margin of the Japan Sea experienced such transtensional deformations in the Early to early Middle Miocene. The crust under NE Japan was broken into blocks but they rotated coherently with dextral transtension.
\end{abstract}

\section{Introduction}

Japanese islands have yielded a wealth of geological and geophysical data to understand the tectonics of subduction zones. The opening of the Japan Sea was merely a short and ancient episode, however, it has given strong control to tectonics of the Japan arc. Deformations that were associated by the event created or enhanced pre-existing weakness of the lithosphere. For example, the faults of which activities created intra-arc rift system are reactivated in the recent compressive stresses and generate big earthquakes at the eastern Japan Sea margin. However, weak and chaotic marine magnetic anomaly hindered a straightforward interpretation of the spreading history of the Japan Sea (Isezaki, 1986; Kono, 1986, 1987; Tamaki and Kobayashi, 1988; Seama and Isezaki, 1990). Ocean Drilling Program, Leg 127 reached igneous basement at three points in the basin (Tamaki et al., 1990). ${ }^{40} \mathrm{Ar} /{ }^{39} \mathrm{Ar}$ dating unlabeled the age of the basement: well examined plateau ages range from 19 to $23 \mathrm{Ma}$ (Kaneoka et al., 1992). In contrast, the paleomagnetic deflection of onshore rocks suggests younger formation of the basin. Accordingly, onshore geology is still important to study how the Japan Sea opened and where destructive earthquakes can occur.

Paleomagnetists have elucidated Early to Middle Miocene tectonic events of the Japan arc_clockwise rotation of SW Japan (Kawai et al., 1961; Otofuji and Matsuda, 1983, 1984, 1987; Otofuji et al., 1985b, 1991; Hayashida and Ito, 1984; Hayashida, 1986), and counterclockwise rotation of NE

*Present address: Japan Weather Association, Nagano Center, Nagano 380-0801, Japan.

**Present address: Department of Biosphere-Geosphere System Science, Faculty of Informatics, Okayama University of Science, Okayama 7000005, Japan.

Copy right(C) The Society of Geomagnetism and Earth, Planetary and Space Sciences (SGEPSS); The Seismological Society of Japan; The Volcanological Society of Japan; The Geodetic Society of Japan; The Japanese Society for Planetary Sciences.
Japan (Otofuji et al., 1985a, c; Tosha and Hamano, 1988). These contrasting rotations reflect the inflection of the arc, implying backarc spreading of the Japan Sea. They interpret that the backarc spreading was coeval with the rotation of the arc (Kawai et al., 1961; Otofuji et al., 1985c, 1991, 1994), significantly younger than the radiometric ages of the igneous basement. These lines of evidence led Hayashida et al. (1991) to suggest that the Japan Sea was not formed through a single episode but at least two stages; one was simultaneous with the magmatic activity of the basement around 20 $\mathrm{Ma}$, and the other was related to the paleomagnetic rotation at about $15 \mathrm{Ma}$.

Since the report by Kawai et al. (1961), northern half of the Japan arc has been considered to be rotated counterclockwise as a single, coherent block. Otofuji et al. (1985c, 1994) provide paleomagnetic data and support the model. However, they found clockwise paleomagnetic deflection in southern NE Japan, perpendicular to the general paleomagnetic direction of NE Japan. Otofuji and his coworkers attribute the discordant directions to minor disturbances due to the strike-slip motion of the Tanakura Shear Zone, a major tectonic line that separates pre-Tertiary basements between SW and NE Japan. Yamazaki (1989) reported clockwise paleomagnetic deflection from the Matsushima area, the Pacific side of NE Japan far off the shear zone. These facts suggest complicated tectonic process in NE Japan, in contrast to the coherent paleomagnetic directions of coeval rock units from SW Japan (Otofuji et al., 1985b). To understand the Japan Sea formation, it is crucial to reveal how the both senses of rotations were accommodated and how they were related to the backarc spreading.

Geological studies, on the other hand, have shown that the crust under NE Japan was strongly extended when the Japan Sea opened and thinning of the crust caused subsidence of NE Japan in the Middle Miocene (Yamaji, 1990; Sato, 1994). Not only extensional but simultaneous strike- 


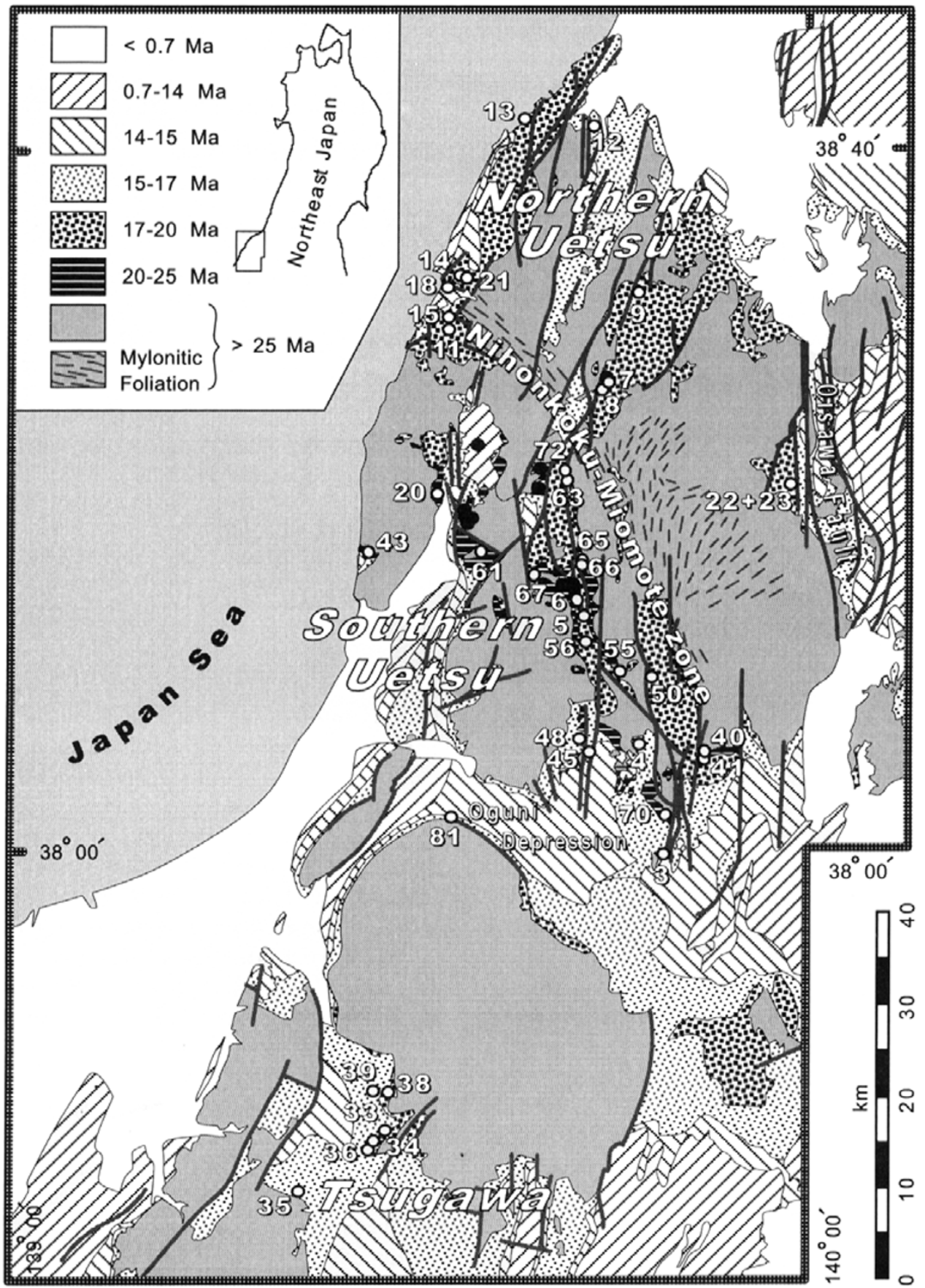

Fig. 1. Sample sites plotted on simplified geologic map. Open circles indicate sites of the present study and closed circles are those of Otofuji et al. (1985c). The Uetsu and Tsugawa areas are divided by the Oguni structural depression. The Nihonkoku-Miomote tectonic zone is defined by mylonitic zone (Shimazu, 1964).

slip movements are suggested (Otsuki, 1975; Yamaji, 1989; Hoshi and Takahashi, 1996), however, the sense and amount of displacements are still controversial because the deformation structures are obliterated by post-extensional sedimentary covers. Such estimations are difficult from geologic structures alone. The southern part of NE Japan arc is suitable for such studies where a number of Early Miocene grabens are exposed and the non-marine graben-fillings intercalate welded tuffs that provide good materials for paleomagnetic studies.
The Uetsu area provides significant constraints because there is a mylonite zone called the Nihonkoku-Miomote Line that is the northern extension of the Tanakura Shear Zone (Shimazu, 1964), one of the largest faults in NE Japan. Some researchers assume a displacement as large as hundreds of kilometers at the Tanakura Shear Zone when the Japan Sea opened (Jolivet and Tamaki, 1992). Paleomagnetic studies suggested block rotations in the Uetsu district and Otofuji et al. (1985c) assume dextral motion along the Nihonkoku-Miomote-Tanakura Shear Zone. In order to un- 

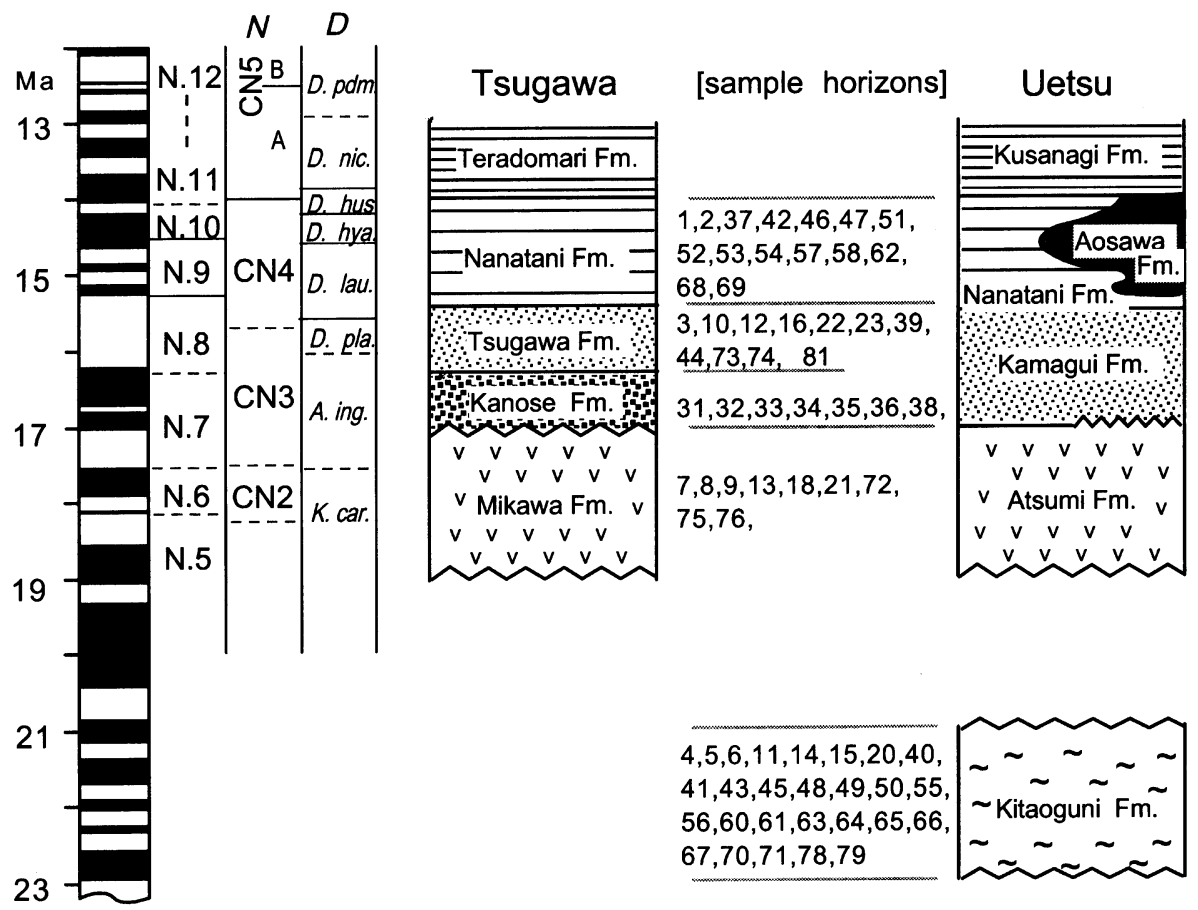

Fig. 2. Neogene stratigraphy of the study area and sample horizons. P: planktonic foraminifer zones, N: calcareous nannofossil zones, D: diatom zones.

derstand intra-arc deformations, we collected paleomagnetic samples at 70 sites in the Uetsu and Tsugawa districts. We will argue the amount of displacement at the tectonic line and how the clockwise and counterclockwise rotations are reconciled.

\section{Geologic Setting}

We collected both volcanic and clastic rocks from the Uetsu area. They are of Early to early Middle Miocene in age. We extended supplementary sampling in the Tsugawa to the south of Uetsu (Fig. 1). Several grabens form the Oguni structural depression (Inaba, 1989) that separates the areas. Reliable remanent magnetism was obtained from 56 sites among a total of 70 localities. The Early to early Middle Miocene sediments fill grabens in the areas of which basement consist of Mesozoic accretion complexes and plutons. The Middle Miocene to Quaternary sediments blanket both holsts and grabens. The Uetsu district is subdivided by the Nihonkoku-Miomote tectonic zone that is defined by the array of left-step, en echelon grabens (Hataya and Otsuki, 1991) and mylonites in the basement. The mylonite zone is often correlated to the northern extension of the Tanakura Shear Zone that separates the pre-Tertiary accretion complexes of NE and SW Japan. The mylonites in the Uetsu and Tanakura areas indicate sinistral shear (Koshiya, 1986; Takahashi, 1998). The offset of basement rocks by the Nihonkoku-Miomote-Tanakura line indicates post midCretaceous displacement at ca. $240 \mathrm{~km}$ (Otsuki, 1992). Yet, its Miocene movement is still controversial.

The stratigraphy of the study area is illustrated with collective names for geologic units in Fig. 2, which basically follows Yamaji $(1989,1990)$. The rhyolitic pyroclastics, lavas, and volcanic breccias called the Kitaoguni Formation occupy the basal part of the Miocene sequence. The pyroclastics have white or purple matrix, and are divided into a number of depositional units (Takahama, 1976; Hataya and Otsuki, 1991). At 27 sites, welded tuffs were sampled from the formation. The Kitaoguni ignimbrite covered most of the Uetsu districts at 21-25 Ma (Yamaji, 1990). Hataya and Otsuki (1991) show that the pyroclastics deposited before the onset of extensional tectonics. Synrift sedimentation began at 18-20 Ma and volcanic and volcaniclastic rocks of the Atsumi and Mikawa Formations filled grabens. The Uetsu and Tsugawa area were inundated by sea water at about 16$17 \mathrm{Ma}$. The Kamagui, Kanose and Tsugawa Formations that consist mainly of lacustrine or shallow marine pyroclastic rocks at that time. The inner NE Japan arc submerged eventually to a few kilometers below sea level. The Aosawa Basalt extruded in the depression. The Miocene formations younger than $15 \mathrm{Ma}$ represent deep sea sediments-they are the Nanatani, Teradomari and Kusanagi Formations, which consist mainly of mudstone with tuffaceous intercalations.

\section{Paleomagnetic Analysis \\ 3.1 Sampling method}

We used a gasoline-powered corer for sedimentary and fine pyroclastic rocks to collect paleomagnetic samples. Hard rocks such as welded tuffs were generally sampled as a hand size block that was prepared into a standard size cylindrical specimens in the laboratory. A magnetic compass was used for the orientation of the samples in the field. A local declination was corrected for each site. A bedding attitude of the strata was measured for sedimentary rocks and fine part of pyroclastic rocks. An eutaxitic texture was measured to determine tilting of welded tuffs. Post emplacement tilting of lava flows was estimated by the attitude of the in- 


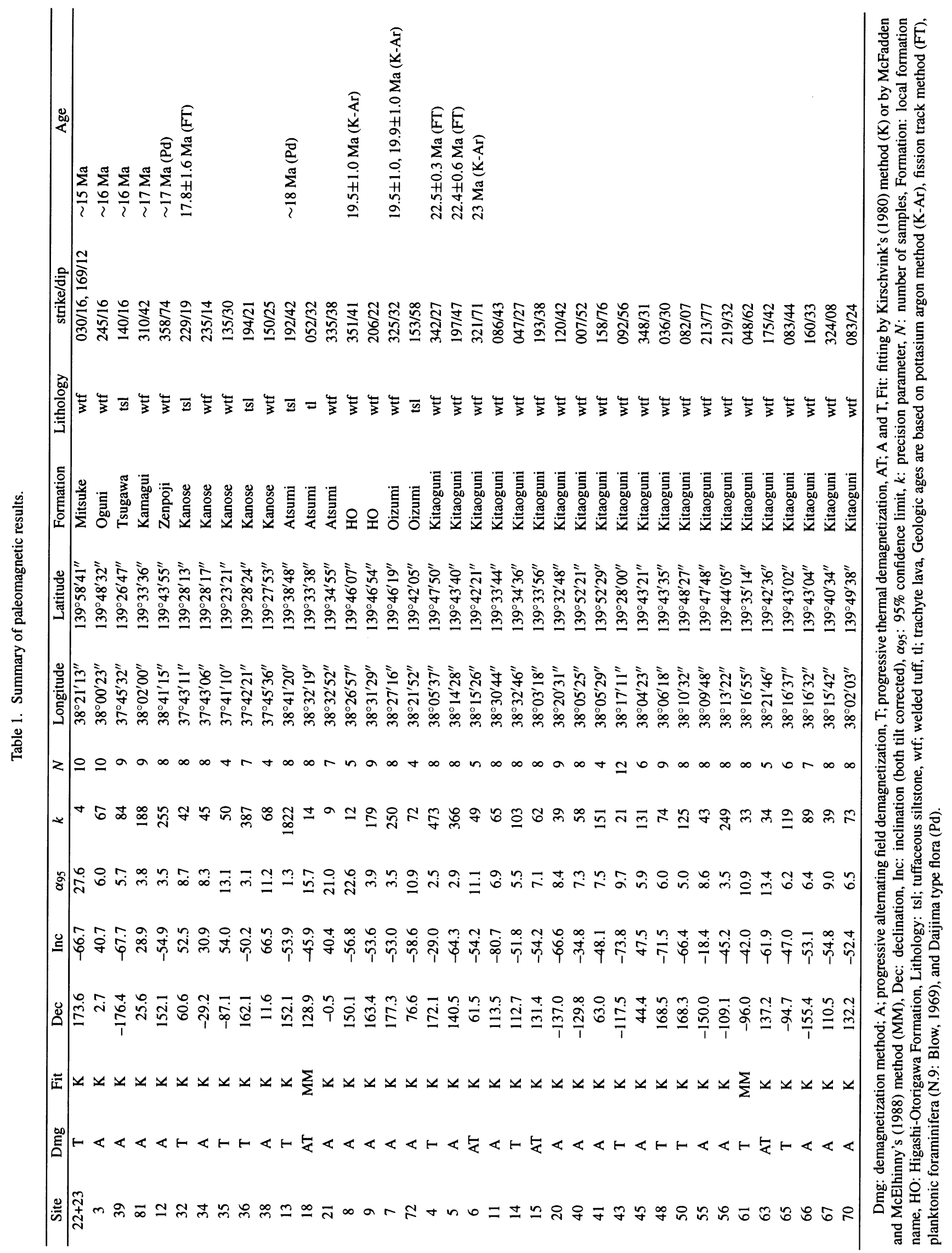


(a) Site 4 [densely welded tuff]

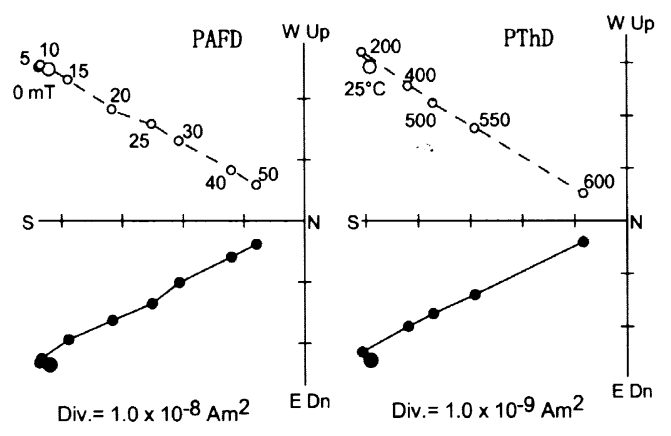

(c) Site 13 [tuffaceous silt]
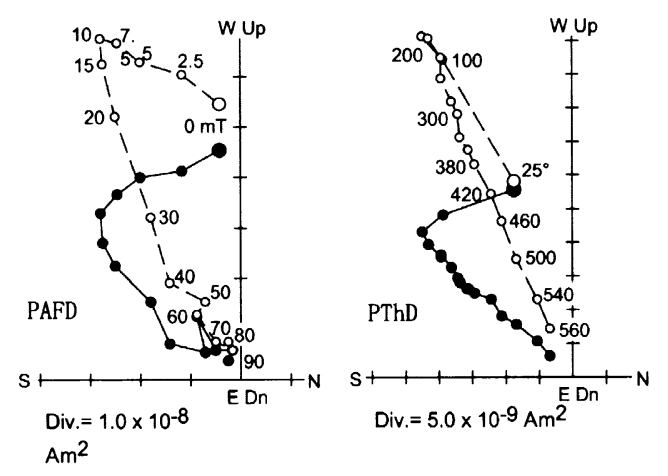

(e) Site 3 [andesite lava]

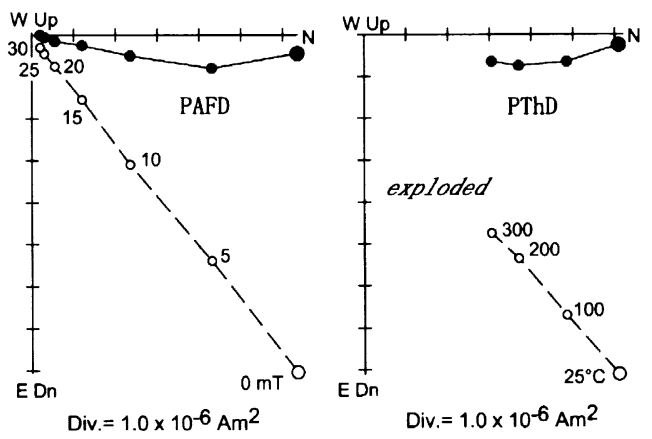

(b) Site 9 [densely welded tuff]

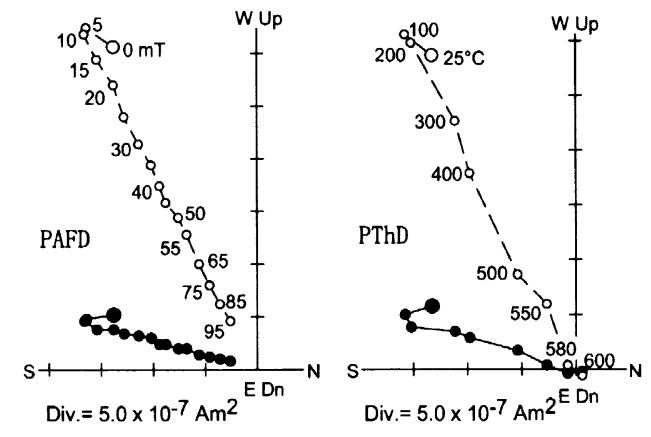

(d) Site 32 [tuffaceous silt]

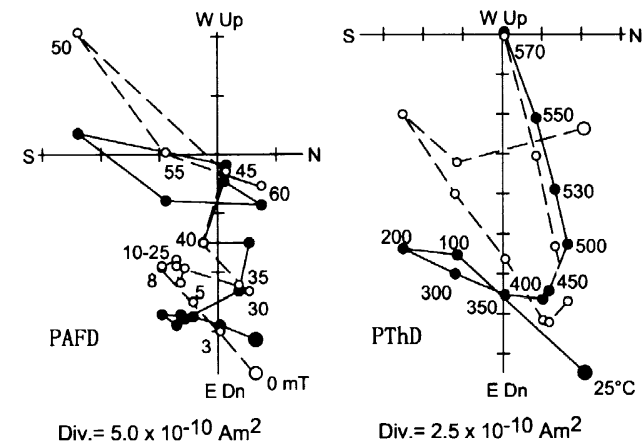

Fig. 3. Vector demagnetization diagrams of typical behaviors. Stable remanent direction for each specimen was determined by the aide of regression of a linear segment on the diagram (Kirschvink, 1980). Open circle denotes a projection on the N-S vertical plane and closed circle on the horizontal plane.

terbedded sediments. Trace of the land-slide was carefully examined for each site by detailed geographic maps. We collected 8 to 10 oriented samples at each site, although some of them were broken during the laboratory sample preparation or heating experiments. Localities of sample sites, local formation names, rock types, and geologic ages are listed on Table 1.

\subsection{Laboratory method}

Natural remanent magnetization (NRM) was measured by using a two-axes cryogenic magnetometer (ScT C-112) and a spinner magnetometer (Schonstedt SSM-1A). Stability and multiplicity of remanence components of each specimen were investigated through the alternating field demagnetization (AFD) and the thermal demagnetization (ThD). The maximum demagnetizing field is $100 \mathrm{mT}$ (peak) and the specimen was rotated by a three-axes tumbler during the demagnetization. Residual field during the cooling cycle of $\mathrm{ThD}$ is controlled less than $5 \mathrm{nT}$ by using four-nested mumetal tubes and a shield-demagnetizing coil attached inside of the mu-metal tubes.

The progressive demagnetization behavior of each specimen was resolved with the principal component analysis method (Kirschvink, 1980), and the combined analysis of great circles and direct observations (McFadden and McElhinny, 1988). An optimum method of the demagnetization was decided for each site judging from the demagnetization behavior of a couple of pilot specimens. When the vector endpoints of the pilot sample make a straight segment towards the origin of a vector demagnetization diagram (Zijderveld, 1967), the high coercivity or high unblock- 
ing temperature directions was obtained with Kirschvink's method. Either progressive AFD or ThD was applied to the rest of the specimens and the stable direction for each specimen was obtained by the linear fitting. Some of the pilot specimens display a curvilinear array of the vector endpoints on the demagnetization diagram, which imply the presence of multiple components of the remanence over particular coercivity/unblocking temperature range. Such sort of specimens were analyzed by combining linear-fitted directions (direct observation) and paths of unterminated great circles, proposed by McFadden and McElhinny (1988). Demagnetization and fitting methods employed for each site are listed on Table 1. Site mean direction was calculated using Fisher statistics (Fisher, 1953).

\subsection{Demagnetization and stable directions}

We obtained stable remanent directions from 56 sites. Unsuccessful sites are mudstone, siltstone and weakly welded tuffs, having very weak NRM intensity and/or unstable behavior of the demagnetization. Most of specimens showed linear array of vector endpoints to the origin of a vector demagnetization diagram except 8 sites where vector endpoints display a curvilinear trend. Typical examples are shown in Fig. 3. After removal of low coercivity/unblocking temperature component, stable component makes linear segment towards the origin of the demagnetization diagram (Fig. 3(a), (b)). It was difficult to know prior to the application whether AFD or ThD was more effective in resolving stable component for each site. Some of the site could only display a linear segment by ThD as shown in Fig. 3(c). The tuffaceous siltstones from the site 32 comprise three remanence components that are only resolved by ThD (Fig. 3(d)). However some of the volcanic rocks were exploded by heating above $300^{\circ} \mathrm{C}$ (Fig. 3(e)). Heating above $300^{\circ} \mathrm{C}$ also raised significant change in magnetic characteristics of some samples, which is attributed to the production of magnetic minerals by the laboratory heating (e.g., Torii et al., 1996). Although the thermal treatment has some difficulties, application of AFD often failed to show linear array of the vector endpoints by acquiring a spurious anhysteretic remanent magnetization (Fig. 3(d)).

The overlapping of coercivity or unblocking temperature of multiple remanence components in one specimen is unavoidable for natural rocks. Such a phenomenon is manifested by a curvilinear array of vector endpoints in the demagnetization diagram as shown in Fig. 4(a). Some of the specimens yield a linear segment, which may depend on sample-size variation, alteration, weathering, etc. The demagnetization behavior of most specimens is expressed by a great circle path on an equal area plot (Fig. 4(c)). If the direction and unblocking temperature of less stable component differ from specimen to specimen, each great circle corresponding individual specimen can not be parallel with each other. And those great circles intersect each other at a particular point on the equal are a projection as shown by Fig. 4(c). Combining direct observation derived from linear behavior of demagnetization (Fig. 4(b)), more credible site mean direction is estimated (McFadden and McElhinny, 1988). Site mean direction were obtained from 3 sites, although samples from 8 sites showed curvilinear array of the vector endpoints. For the rest of the sites, great circles were

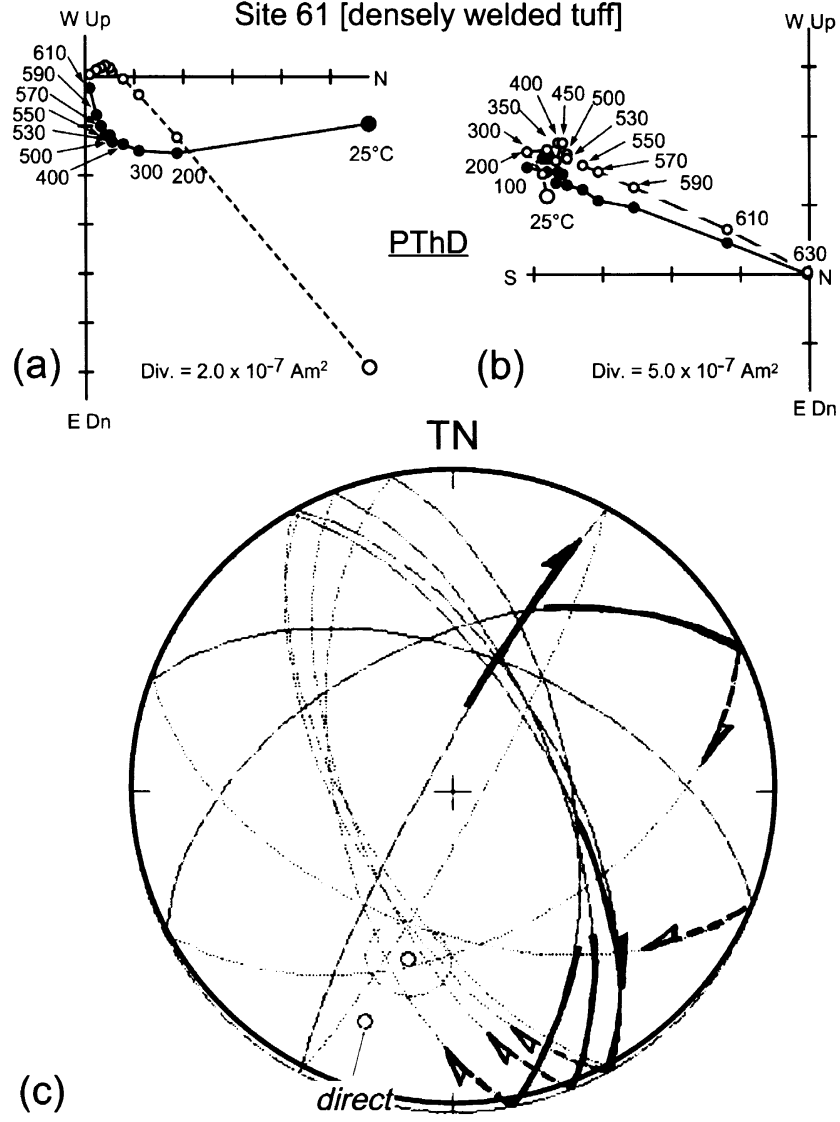

Fig. 4. Site-mean direction estimated with a combined analysis of great circle and direct observation proposed by McFadden and McElhinny (1988).

intersect each other but only showing considerable scatter with $95 \%$ confidence limit greater than 30 degrees.

Through the demagnetization experiments, we could determine characteristic directions from 50 and 6 sites in the Uetsu and Tsugawa districts, respectively. However some of them were discarded from a further examination because of the following reasons: (1) a large scatter of site mean direction $\left(\alpha_{95}>30^{\circ}\right)$, (2) a small number of samples $(N<4)$, and (3) coincidence with the direction of geocentric axial dipole field before a tilt correction. Thus remanence directions from 43 sites were subjected to tilt correction as described below.

\subsection{Tilt correction}

The site mean directions of 43 sites were tilt-corrected to an assumed original horizontal, by the conventional simple correction. Two sites were not processed because of poorly defined structural attitude at the sample sites. The other two sites were discarded because they showed very shallow inclination $\left(I<10^{\circ}\right)$ by untilting, possible recording a transitional geomagnetic field. Tilt corrected directions of 38 sites are listed in Table 1 and Fig. 5.

We applied the tilt correction by subdividing the Uetsu district into two sub-districts. The northern sub-district to the north of the Nihonkoku-Miomote mylonites (Fig. 1), where the site mean directions from 12 sites show a coherence of declinations after the tilt correction (Fig. 5(a)). The concentration parameter $(k)$ before tilt correction is 7.0 and increases to 25.4 by untilting. The result is significant at $99 \%$ confi- 

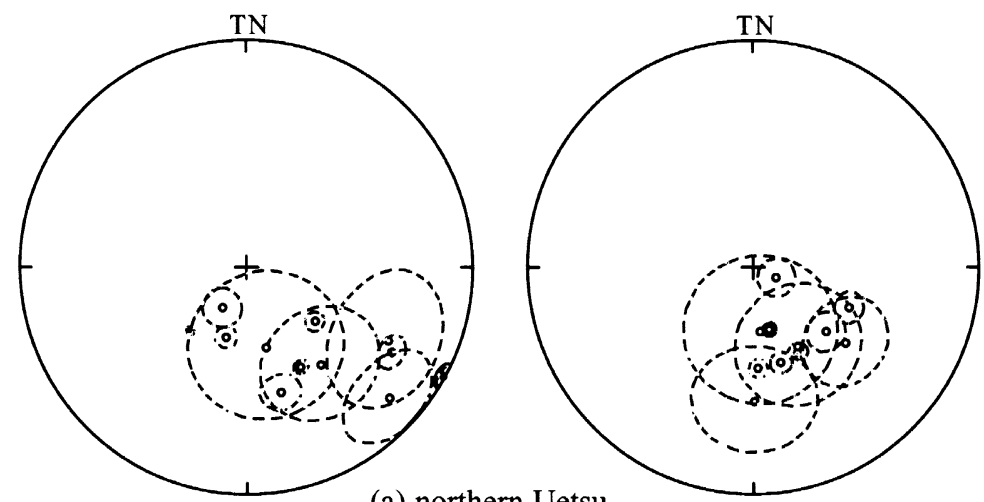

(a) northern Uetsu

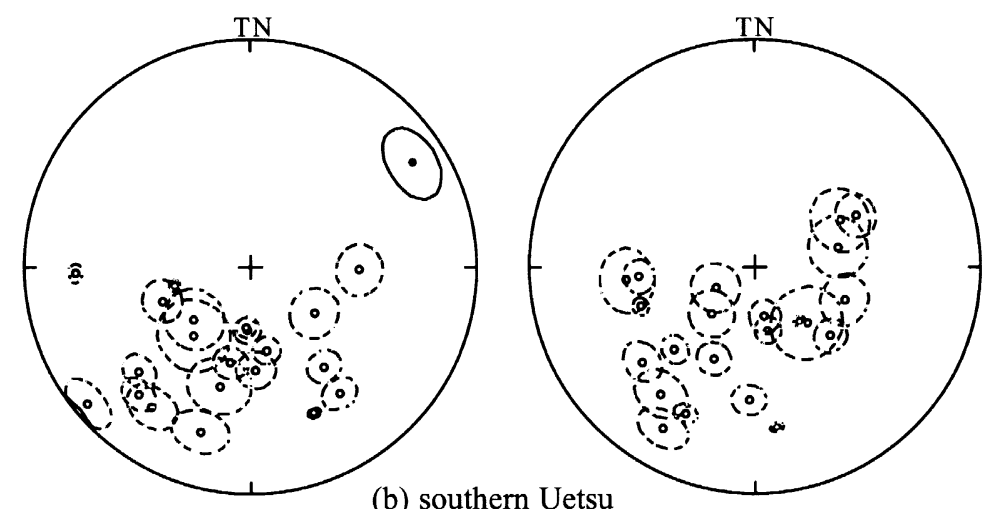

(b) southern Uetsu

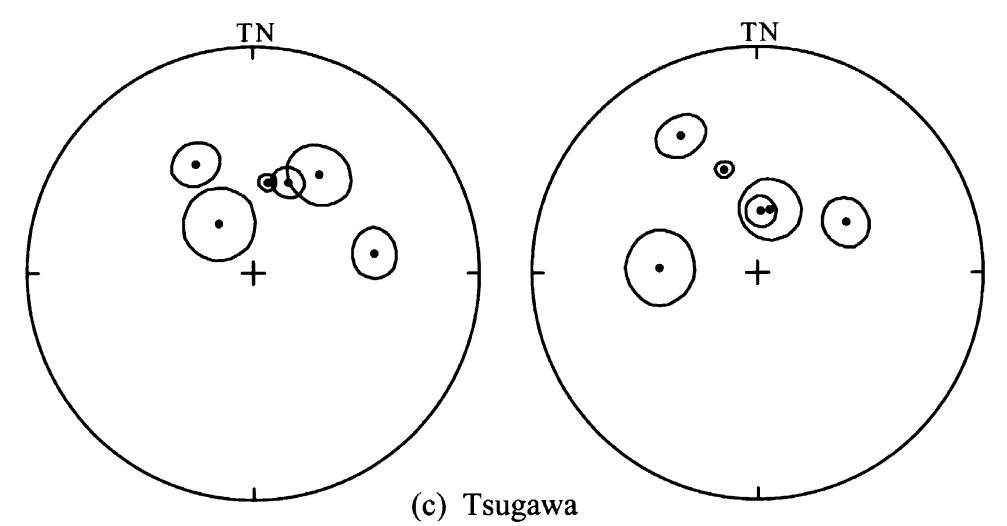

Fig. 5. Tilt correction of characteristic site-mean directions. Equal area plots in left column are of geographic coordinate and plots on right column are of stratigraphic coordinate. (a) Northern Uetsu pass the statistical criterion at 99\% confidence level of McElhinny (1964). (b) Clockwise and counterclockwise declinations from the southern Uetsu area before and after tilt correction. (c) Result from the Tsugawa district do not pass the statistical criteria of tilt correction, although does not coincide with the dipole field direction. All directions are converted either upper hemisphere (a and b) or lower hemisphere (c) according to a dominant polarity.

dence limit according to the fold test criteria proposed by McElhinny (1964).

While the fold test was successfully applied to the northern Uetsu sub-district to the north of the Nihonkoku-Miomote mylonites, the southern sub-district yields scattered declinations after the tilt correction (Fig. 5(b)). We interpret that the unsuccessful fold test is reflecting various modes of rotation around a vertical axis. This is suggested by the increase in convergence of inclinations after the tilt correction while declinations still be scattered. In order to evaluate convergence of inclination values, we applied an inclination statistics after the method of Kono (1980). Before the tilt correction, the mean inclination is $47.8^{\circ}$ and $k$ is 8.6 for 22 sites. After the tilt correction, the mean inclination increased to $52.8^{\circ}$ which is almost compatible with the dipole field inclination $\left(I=57^{\circ}\right)$ and $k$ also increased to 13.3 . If we simply applied the conventional McElhinny's criteria, $k$ ratio does not pass at $95 \%$ confidence limit, however. McElhinny's method was criticized as under estimation of the confidence limit and much improved method was proposed by McFadden (1990). However it is not possible to apply McFadden's method to the inclination data set. We therefore thought that the increase in $k$ for inclinations safely implies the primary acquisition of each site-mean directions before tilting of the strata. And the primary directions were scattered by various modes of rotation around the vertical axis to bring highly scattered 


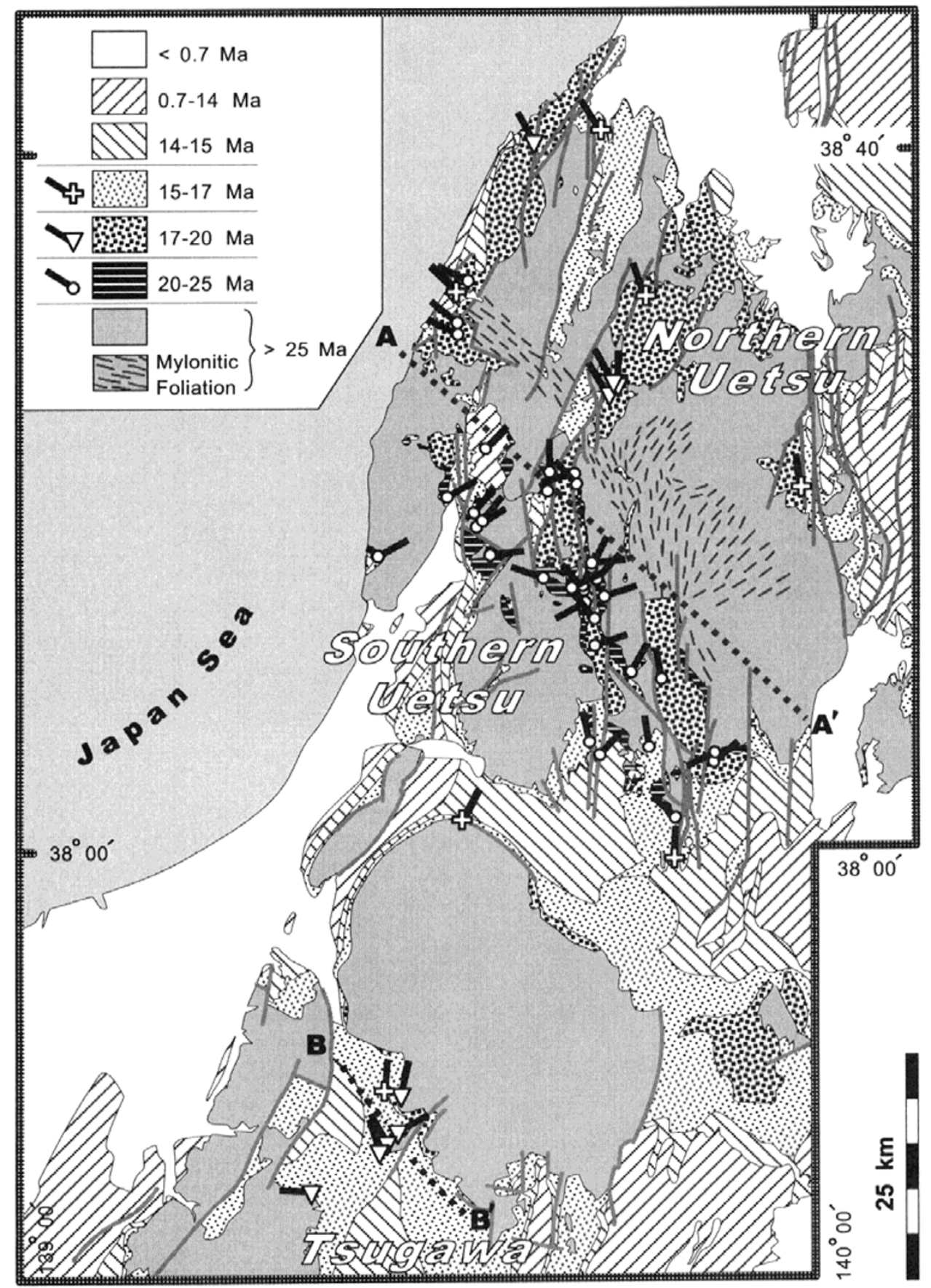

Fig. 6. Paleomagnetic directions plotted on geologic map of the Uetsu and Tsugawa areas. Symbol: bar = paleomagnetic direction, circle $=20-35$ Ma sample, triangle $=17-20$ Ma sample, cross $=15-17$ Ma sample.

declinations. The convergence in inclination also excludes possibility of the net tectonic rotation that is suggested by MacDonald (1980).

Only 6 sites yielded characteristic directions from the Tsugawa district. These site mean directions show clockwise and counterclockwise deflections same as the southern part of Uetsu district (Fig. 5(c)). By applying a tilt correction, $k$ decreases from 9.8 to 7.8 indicating insignificance of the fold test. We also tested inclination statistics and could not find any significant result: $k$ decreased from 52 to 17 by untilting. Although it is difficult to regard those direc- tions to be a primary one on the basis of statistics, they do not coincide with the dipole field direction before untilting. (The site 36 has zero declination after plotted onto to a lower hemisphere as shown in Fig. 5(c), the original inclination is negative.) The scatter in declination is possibly reflecting a local tectonics.

Finally paleomagnetic directions from 38 sites including that of the Tsugawa area are listed in Table 1. Their declinations are plotted on the geological map on Fig. 6 by converting negative inclination to positive one. In the following discussion, we simply regard the untilted declination to indicate 


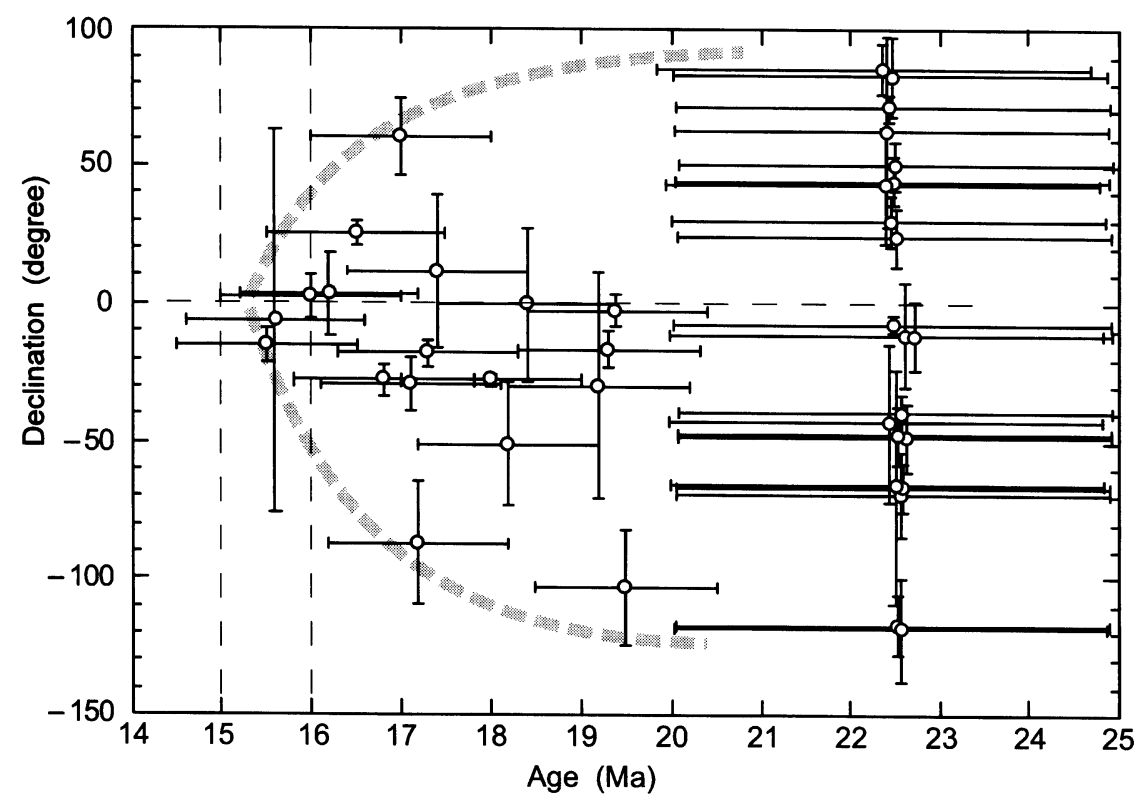

Fig. 7. Paleomagnetic declination versus sample age. Dotted lines $=$ upper and lower limits of declination.

amount of tectonic rotation about a vertical axis. Although we have to correct declination to the expected declination of the particular age for a strict application (Beck, 1980), we do not fixed original declinations at all, because (1) our primary purpose is to elucidate differential movements in NE Japan, and (2) the suggested pole position for Northern Eurasia does not differ very much from the geographic pole for 20 to 10 Ma (Irving and Irving, 1982).

\section{Discussion}

Paleomagnetism shows complicated deformation in the Uetsu and Tsugawa districts. The results allow us to subdivide the Uetsu district into two areas by the dashed line $\mathrm{AA}^{\prime}$ in Fig. 6. The northeastern area was undergone a coherent, counterclockwise rotation. Their average deflection is similar to that from most of NE Japan (Otofuji et al., 1985c). In contrast, the paleomagnetic data indicate complicated deformations in the southwestern Uetsu and Tsugawa areas where clockwise and counterclockwise deflections are found. It should be noted that most of the samples with clockwise paleomagnetic deflection were taken from the Kitaoguni Formation, suggesting that the direction indicates a short-term geomagnetic fluctuation rather than tectonic movements. However, pyroclastic rocks as young as 16 Ma yields such paleomagnetic directions also (Fig. 7). In addition, a number of clockwise paleomagnetic directions were found recently in the southern Uetsu area from the Atsumi Formation (Mino, personal communication). Therefore, the paleo geomagnetic fluctuation is unlikely.

Assuming the Nihonkoku-Miomote tectonic zone as a northwestern extension of the Tanakura Shear Zone, Otofuji et al. (1985c) attributed clockwise paleomagnetic deflection to the dextral motion of the zone. However, the zone in which block rotation occurred is wider than Otofuji and his colleagues thought (Fig. 6). Block rotation occurred in a wide zone. The line $\mathrm{AA}^{\prime}$ in Fig. 6 shows the northeastern border of the zone. Our data is not enough to delineate the other boundary, however, the samples to the west of the line $\mathrm{BB}^{\prime}$ show counterclockwise deflections. The zone with clockwise deflections seems to include eastern Tsugawa district as well as southern Uetsu area.

The area to the southeast of the zone seems to have rotated counterclockwise like the northern Uetsu area: Hirooka et al. (1986) obtained paleomagnetic directions from Early Miocene rocks with the mean declinations at $333^{\circ}$ and $346^{\circ}$ in the Sado and Fukushima areas, respectively. Therefore, the zone of clockwise deflections is sandwiched by the areas with opposite paleomagnetic deflections.

Dextral shear was suggested in the zone by Hataya and Otsuki (1991) as Early Miocene grabens are arranged in a left-step en echelon manner. The paleomagnetic rotations in the same zone is consistent with the dextral shear. Our data has a poor temporal resolution, but we interpret the timing of the block rotation at 15-20 Ma, simultaneous with the large-scale extensional deformation of the arc (Yamaji, 1990; Sato, 1994). Otsuki (1975) and Koshiya (1986) show a simultaneous dextral shear in the Tanakura area.

The zone is bounded at the northeastern side by the line $\mathrm{AA}^{\prime}$ in Fig. 6. The Nihonkoku-Miomote mylonitic zone seems to have affected the Miocene rotation. The zone of block rotations is parallel to the line that is characterized by granitic mylonites. Their foliations dip southwest at around 50 degrees with sinistral and normal senses of movements (Takahashi, 1998). Takahashi interprets the timing of mylonitization before $92 \mathrm{Ma}$. Accordingly, in the Early Miocene time, the hanging wall of the ancient ductile shear zone was broken into blocks by transtensional tectonics when the Japan Sea opened. The granitic mylonites intercalate the slabs of biotite-muscovite schists that are fissile and much weaker than the granitic mylonites and may have worked as zones 
of pre-existing weakness under the rotating blocks in the Miocene. The hanging wall may have broken into blocks that rotated clockwise by the dextral shear along the zone.

Although our data have not enough resolution to constrain the timing of the rotation, the primary site-mean directions suggest that rotation was occurring until $\sim 15 \mathrm{Ma}$ in the Uetsu and Tsugawa areas. The temporal variations in the direction are estimated to range from $23 \mathrm{Ma}$ to $15 \mathrm{Ma}$ on the basis of radiometric and fossil ages. Our data show a wide range of rotation, though, the angular variation decreased toward $\sim 15$ Ma (Fig. 7). The youngest paleomagnetic data was brought from the Kamagui Formation that is correlated with Blow's (1969) foraminifer zone N. 8 (15.1-16.4 Ma). The Kitaoguni Formation yields the oldest paleomagnetic data in this study, which was radiometrically dated at about 21 to $23 \mathrm{Ma}$ (Ueda et al., 1973; Ganzawa, 1987). The tectonostratigraphy of the Uetsu area indicates that transtensional deformation began after the deposition of the Kitaoguni Formation and ceased at about $15 \mathrm{Ma}$ (Yamaji, 1990), concordant with our paleomagnetic data.

Northern Uetsu area rotated counterclockwise as a single block more or less. In contrast, the crust under the southern Uetsu area was broken into a number of spinning blocks. The paleomagnetic declination of the northern Uetsu block is similar to that of most NE Japan (Otofuji et al., 1985c). Accordingly, Otofuji and his coworkers interpret the NE Japan arc was rotated as a coherent block that was bounded on its southwestern side by the Tanakura Shear Zone, simultaneously with the coherent rotation of SW Japan at ca. 15 Ma. However, this interpretation is unsatisfactory, because tectonostratigraphy indicate that the crust under NE Japan was broken into a number of blocks in Early to early Middle Miocene (Yamaji, 1990), and because inconsistent clockwise paleomagnetic direction were also found in the Pacific side of Northeast Japan. Recently, Hoshi and Takahashi (1997) indicate that the southern part of NE Japan frontal arc has not rotated since $18 \mathrm{Ma}$. In addition, the preliminary study by Oda et al. (1989) shows that the Yanagawa area was rotated clockwise (Fig. 8). Consequently, paleomagnetic data so far reported indicate that most of NE Japan rotated counterclockwise but some areas yield little or opposite sense of rotations.

In relation with tectonostratigraphy, we interpret that dextral transtension accompanied these rotations. Kobayashi (1941) summarized tectonostratigraphy of Japan and assumed the Kwanto Tectonic Line of which dextral movement transferred the NE Japan frontal arc southeastward. Recent paleomagnetic work by Otofuji et al. (1997) supports this hypothesis. Kitamura (1963) realized that Neogene strata in NE Japan suggest the differential movements of blocks which were bounded by NW-SE trending faults, they are the Hachirogata-Ichinoseki (HI), Honjo-Matsushima (HM), Nishikawa-Takarazawa (NT), Tanakura Shear Zone (Fig. 8). Ehiro (1982) suggests that en echelon folds near the Futaba Fault were formed by the dextral motion of the fault in the Miocene. Perhaps the clockwise paleomagnetic rotations were accompanied by the dextral motion of these faults. The dextral shear between the HM and NT lines may have created a number of grabens there (Nakamura, 1996) and clockwise paleomagnetic rotations in the Matsushima and Yanagawa

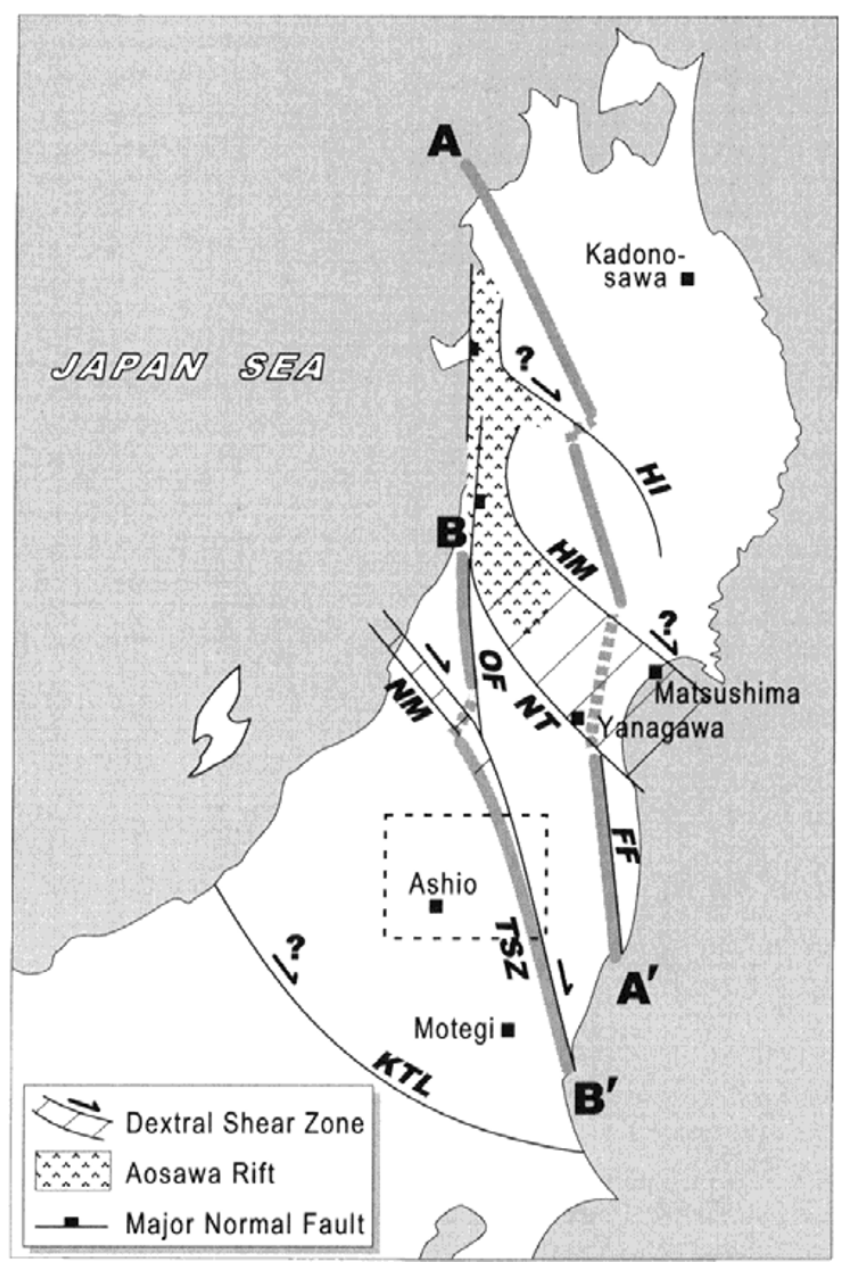

Fig. 8. Schematic of the Miocene dextral transtensional deformations in NE Japan inferred from paleomagnetism and tectonostratigraphy. Thick gray lines $\mathrm{AA}^{\prime}$ and $\mathrm{BB}^{\prime}$ show the eastern and western boundary of the Abukuma Belt (Kubo and Takahashi, 1992). Dashed line show the Fukushima area where Hirooka et al. (1986) obtained counterclockwise paleomagnetic declinations. FF: Futaba Fault, HI: Hachirogata-Ichinoseki, HM: Honjo-Matsushima, NT: Nishikawa-Takarazawa, NM: Nihonkoku-Miomote Lines (Kitamura, 1963). OF: Oisawa Fault, TSZ: Tanakura Shear Zone, KTL: Kwanto Tectonic Line.

areas, which Oda et al. (1989) found. In the Matsushima district, such a movement may have terminated at about 16 Ma when the angular unconformity was formed between the sequences correlated to diatom biozones Denticulopsis ingens and D. praelauta (Ishii et al., 1983; Yamazaki, 1989).

The zonal structures of the pre-Tertiary basement are also offset in the dextral sense at those zones. Both the eastern and western borders of the Abukuma Belt seem to kink at the intersections with the HI, HM, NT and Nihonkoku-Miomote lines (Kubo and Takahashi, 1992). The dextral shear may have been linked with the NS trending normal fault zone at the western end - the depression of the Aosawa intra-arc rift (Tsuchiya, 1989; Yamaji, 1990; Sato, 1994) was an example. The dextral shear between the HM and NT lines might have made the depression (Fig. 8). The intra-arc rift worked as a deep sedimentary basin for Neogene sediments. The zone has been reactivated as a thrust zone by east-west compression since the latest Miocene and is used as loci of crustal 
earthquakes (Ozawa et al., 1989; Okamura et al., 1995). Accordingly, Early to early Middle Miocene dextral transtension at the eastern Japan Sea margin has given strong control not only to paleomagnetic rotations but also Neogene sediment accumulations and recent compressional deformations in NE Japan.

We interpret the both senses of paleomagnetic rotations in NE Japan by the counterclockwise overall rotation of the arc and by dextral transtension therein (Fig. 8). Jolivet et al. (1995) present a similar interpretation. Their model differs from ours in that they attribute most of the counterclockwise paleomagnetic deflection in NE Japan to intra-arc block rotation as much as 60 degrees. They assume that the frontal arc rotated counterclockwise by 20-30 degrees. Blocks in the inner arc rotated more. They interpret the difference by a few tens of degrees by counterclockwise rotation of the blocks. Accordingly, the model equals Lallemand and Jolivet's (1986) 'pull-apart opening' plus intra-arc block rotations. We agree that the crust under NE Japan was broken into blocks, and we accept that there were block rotations because the frontal arc seems to have ceased rotation before the inner arc by a few million years (Hoshi and Takahashi, 1997). However, we interpret that most of the counterclockwise paleomagnetic rotation represents the general rotation of the NE Japan arc. Namely, the principal behavior of the blocks was coherent, counterclockwise rotation, but they were rotated more with respect to the frontal arc that ceased rotation earlier. The sharp difference between Jolivet et al.'s (1995) and our models is how much the blocks rotated with respect to the frontal arc. We prefer smaller amount of block rotation. There are two lines of evidence. First, the frontal arc, such as the Kadonosawa district (Hayashida, 1994; Hoshi and Matsubara, 1998), rotated as much as the inner arc. Second, the counterclockwise block rotations in the backarc region should have resulted in the left-lateral displacement of the blocks with respect to the less rotational frontal arc. As Lallemand and Jolivet (1986) emphasized, the right-lateral motion of the NE Japan arc with respect to Eurasia accompanied the Japan Sea opening no matter how the drifting arc was deformed. Therefore, the large block rotations such as Jolivet et al. (1995) assumed appear difficult to reconcile with the overall, right-lateral shear at the eastern Japan Sea margin.

Acknowledgments. We thank H. Oda, K. Fukuma, N. Ishikawa, and K. Mino for sampling. D. Miki and Y. Furukawa kindly assisted with numerical analyses. Some of the sample localities were recommended by M. Inaba. This work was partly supported by the Grant-in-Aid for Scientific Research (AY, 01790345, 08640568; MT, 03302023) from the Ministry of Education, Science and Culture.

\section{References}

Beck, M. E., Jr., Paleomagnetic record of plate-margin tectonic processes along the western edge of North America, J. Geophys. Res., 85, 71157131, 1980.

Blow, W. H., Late Middle Eocene to Recent planktonic foraminiferal biostratigraphy, Proc. 1st Int. Conf. Planktonic Fossils, 199-422, 1969.

Ehiro, M., NNW-SSE faults in Northeast Japan, Earth Monthly, 4, 200-205, 1982.

Fisher, S. R., Dispersion on a sphere, Proc. Roy. Soc. Ser. A, 217, 295-305, 1953.

Ganzawa, Y., Fission track ages of volcanic rocks from Cretaceous to Ter- tiary in the inner belt of Northeast Japan-Okushiri Island, Oga Peninsula and Asahi Mountains, J. Geol. Soc. Japan, 93, 387-401, 1987.

Hataya, R. and K. Otsuki, Geology of the Oguni-machi area, Yamagata Prefecture: An example of Early Miocene half-grabens in Northeast Honshu Arc, J. Geol. Soc. Japan, 97, 835-848, 1991.

Hayashida, A., Timing of rotational motion of southwest Japan inferred from paleomagnetism of the Setouchi Miocene series, J. Geomag. Geoelectr., 38, 295-310, 1986.

Hayashida, A., Paleomagnetic directions in the Kadonosawa district and the rotation of NE Japan, Earth Monthly, 16, 135-138, 1994.

Hayashida, A. and Y. Ito, Paleoposition of southwest Japan at $16 \mathrm{Ma}$ : implication from paleomagnetism of the Miocene Ichishi Group, Earth Planet. Sci. Lett., 68, 335-342, 1984.

Hayashida, A., T. Fukui, and M. Torii, Paleomagnetism of the early Miocene Kani Group in Southwest Japan and its implication for the opening of the Japan sea, Geophys. Res. Lett., 18, 1095-1098, 1991.

Hirooka, K., H. Sakai, T. Takahashi, H. Kinoto, and A. Takeuchi, Tertiary tectonic movement of Central Japan infrared from paleomagnetic studies, J. Geomag. Geoelectr., 38, 311-324, 1986.

Hoshi, H. and T. Matsubara, Early Miocene paleomagnetic results from the Ninohe area, NE Japan: implications for arc rotation and intra-arc differential rotation, Earth Planets Space, 50, 23-33, 1998.

Hoshi, H. and M. Takahashi, Stratigraphy and geologic structure of the Lower Miocene in the Motegi area: the relationship between N-S trending fault activity and tectonics in Miocene Northeast Japan, J. Geol. Soc. Japan, 102, 25-39, 1996.

Hoshi, H. and M. Takahashi, Paleomagnetic constraints on the extent of tectonic blocks and the location of their kinematic boundaries: implications for Miocene intra-arc deformation in Northeast Japan, J. Geol. Soc. Japan, 103, 523-542, 1997.

Inaba, M., Formation of the Miocene sedimentary basin in the Echigoshimoseki District, Niigata Prefecture, Japan, Assoc. Geol. Collaboration Japan Monogr., No. 36, 143-160, 1989.

Irving, E. and G. A. Irving, Apparent polar wander paths Carboniferous through Cenozoic and the assembly of Gondwana, Geophys. Surv., 5, 141-188, 1982.

Isezaki, N., A magnetic anomaly map of the Japan sea, J. Geomag. Geoelectr., 38, 403-410, 1986.

Ishii, T., Y. Yanagisawa, and S. Yamaguchi, Geology of the Shiogama District, Quadrangle Series, scale 1:50,000, Geol. Surv. Japan, 112 pp., 1983.

Jolivet, L. and K. Tamaki, Neogene kinematics in the Japan Sea region and the volcanic activity of the Northeast Japan arc, in Proc. ODP, Sci. Results, 127/128, edited by K. Tamaki et al., pp. 1311-1331, U.S. Government Printing Office, Washington D.C., 1992.

Jolivet, L., H. Shibuya, and M. Fournier, Paleomagnetic rotations and the Japan Sea opening, in Active Margins and Marginal Basins of the Western Pacific, pp. 355-369, Am. Geophys. Union, Washington, D.C., 1995.

Kaneoka, I., Y. Takigami, N. Takaoka, S. Yamashita, and K. Tamaki, ${ }^{40} \mathrm{Ar} /{ }^{39} \mathrm{Ar}$ analysis of volcanic rocks recovered from the Japan Sea floor by Legs 127 and 128: constraints on the age of formation of the Japan Sea, in Proc. ODP, Sci. Results, 127/128, edited by K. Tamaki et al., pp. 475-486, U.S. Government Printing Office, Washington D.C., 1992

Kawai, N., H. Ito, and S. Kume, Deformation of the Japanese Island as inferred from rock magnetism, Geophys. J. Roy. astr. Soc., 6, 124-129, 1961.

Kirschvink, J., The least-squares line and plane and the analysis of paleomagnetic data, Geophys. J. Roy. astr. Soc., 62, 699-718, 1980.

Kitamura, N., Tertiary tectonic movements of the Green Tuff area, Kaseki, 5, 124-137, 1963.

Kobayashi, T., The Sakawa orogenic cycle and its bearing on the origin of the Japanese islands, J. Fac. Sci. Imp. Univ. Tokyo, Sec. II, 5, 219-578, 1941.

Kono, M., Statistics of paleomagnetic inclination data, J. Geophys. Res., 85 , 3878-3882, 1980.

Kono, M., Magnetic anomalies on the sea of Japan: A speculation on the tectonic history, J. Geomag. Geoelectr., 38, 411-426, 1986.

Kono, M., Controversy on the opening of the Japan Sea, EOS, 68, 1146, 1987.

Koshiya, S., Tanakura Shear Zone: the deformation process of fault rocks and its kinematics, J. Geol. Soc. Japan, 92, 15-29, 1986.

Kubo, K. and Y. Takahashi, Eastern and western boundaries of the Abukuma belt with special reference to the Abukuma and Kitakami granitic rocks, Abstracts of the 46th Ann. Meeting Assoc. Geol. Collaboration in Japan, pp. 111-115, 1992.

Lallemand, S. and L. Jolivet, Japan Sea: a pull-apart basin?, Earth Planet. 
Sci. Lett., 76, 375-389, 1986.

MacDonald, W. D., Net tectonic rotation, apparent tectonic rotation, and the structural tilt correction in paleomagnetic studies, J. Geophys. Res., 85, 3659-3669, 1980

McElhinny, M. W., Statistical significance of the fold test in palaeomagnetism, Geophys. J. Roy. astr. Soc., 8, 338-340, 1964.

McFadden, P. L., A new fold test for paleomagnetic studies, Geophys. J. Int., 103, 163-169, 1990.

McFadden, P. L. and M. W. McElhinny, The combined analysis of remagnetization circles and direct observations in palaeomagnetism, Earth Planet. Sci. Lett., 87, 161-172, 1988 .

Nakamura, K., Subsidence-uplift and transgression-regression, the Sendai Bay, in Computer Graphics, the Geology of Japanese Islands, edited by Editorial Group for Computer Graphics, Geology of Japanese Islands, pp. 72-75, Maruzen Co., Tokyo, 1996.

Oda, H., M. Torii, and A. Hayashida, Paleomagnetic study and fissiontrack dating in Yanagawa and Takadate area, Northeast Japan, Rock Mag. Paleogeophys., 16, 51-56, 1989.

Okamura, Y., N. Watanabe, R. Morijiri, and M. Satoh, Rifting and basin inversion in the eastern margin of the Japan Sea, Island Arc, 4, 166-181, 1995.

Otofuji, Y. and T. Matsuda, Paleomagnetic evidence for the clockwise rotation of Southwest Japan, Earth Planet. Sci. Lett., 62, 349-359, 1983.

Otofuji, Y. and T. Matsuda, Timing of rotational motion of southwest Japan inferred from paleomagnetism, Earth Planet. Sci. Lett., 70, 373-382, 1984

Otofuji, Y. and T. Matsuda, Amount of clockwise rotation of Southwest Japan-fan shape opening of the southwestern part of the Japan Sea, Earth Planet. Sci. Lett., 85, 259-301, 1987.

Otofuji, Y., A. Hayashida, and M. Torii, When was the Japan Sea opened? Paleomagnetic evidence from Southwest Japan, in Formation of Active Ocean Margins, edited by N. Nasu et al., pp. 551-566, Terrapub, Tokyo, $1985 \mathrm{a}$

Otofuji, Y., T. Matsuda, and S. Nohda, Paleomagnetic evidence for the Miocene counter-clockwise rotation of northeast Japan-rifting process of the Japan arc, Earth Planet. Sci. Lett., 75, 265-277, 1985b.

Otofuji, Y., T. Matsuda, and S. Nohda, Opening mode of the Japan Sea inferred from the paleomagnetism of the Japan arc, Nature, 317, 603, $1985 \mathrm{c}$

Otofuji, Y., T. Itaya, and T. Matsuda, Rapid rotation of southwest Japanpaleomagnetism and K-Ar ages of Miocene volcanic rocks of southwest Japan, Geophys. J. Int., 105, 397-405, 1991.

Otofuji, Y., A. Kambara, T. Matsuda, and S. Nohda, Counterclockwise rotation of Northeast Japan: Paleomagnetic evidence for regional extent and timing of rotation, Earth Planet. Sci. Lett., 121, 503-518, 1994.

Otofuji, Y., Y. Nishizawa, M. Tamai, and T. Matsuda, Paleomagnetic and chronological study of Miocene welded tuffs in the northern part of Central Japan: tectonic implications for the latest stage of arc formation of Japan, Tectonophys., 283, 263-278, 1997.

Otsuki, K., Geological structure of the Tanakura Tectonic Zone, Contrib. Inst. Geol. Paleont. Tohoku Univ., 76, 1-70, 1975.
Otsuki, K., Oblique subduction, collision of microcontinents and subduction of oceanic ridge: their implications on the Cretaceous tectonics of Japan, Island Arc, 1, 51-63, 1992.

Ozawa, A., N. Tsuchiya, T. Katahira, Y. Kikuchi, and T. Ohguchi, Subsurface structure under the oil fields in southern Akita and northern Yamagata Prefecture, Mem. Geol. Soc. Japan, 32, 133-142, 1989.

Sato, H., The relationship between late Cenozoic tectonic events and stress field and basin development in Northeast Japan, J. Geophys. Res., 99, 22261-22274, 1994.

Seama, N. and N. Isezaki, Sea-floor magnetization in the eastern part of the Japan Basin and its tectonic implications, Tectonophys., 181, 285-297, 1990.

Shimazu, M., Cretaceous Granitic rocks in northeast Japan (I), Earth Sci. (Chikyu Kagaku), 71, 18-27, 1964.

Takahama, N., The Neogene stratigraphy in the northern part of Niigata Prefecture, Japan, Contrib. Dep. Geol. Min. Niigata Univ., 4, 97-104, 1976.

Takahashi, Y., Geology and structure of the Nihonkoku Mylonite Zone on the borders of Niigata and Yamagata Prefectures, northeast Japan, J. Geol. Soc. Japan, 104, 122-136, 1998.

Tamaki, K. and K. Kobayashi, Geomagnetic anomaly lineation in the Japan Sea, Kaiyo, 20, 705-710, 1988.

Tamaki, K., K. Pisciotto, and J. Allan, Background, objectives, and principal results, ODP Leg 127, Japan Sea, in Proc. ODP, Init. Repts., 127, 5-33, 1990.

Torii, M., K. Fukuma, C.-S. Horng, and T.-Q. Lee, Magnetic discrimination of pyrrhotite- and greigite-bearing sediment samples, Geophys. Res. Lett., 23, 1813-1816, 1996.

Tosha, T. and Y. Hamano, Paleomagnetism of Tertiary rocks from the Oga peninsula and the rotation of northeast Japan, Tectonics, 7, 653-662, 1988 .

Tsuchiya, N., Submarine basalt volcanism of Miocene Aosawa Formation in the Akita-Yamagata oil field, back-arc region of Northeast Japan, Mem Geol. Soc. Japan, 32, 399-408, 1989.

Ueda, Y., N. Jinbo, and R. Tamiya, K-Ar dating of a lower Neogene welded tuff in Yamagata Prefecture, J. Japan. Assoc. Pet. Technol., 54, 179-193, 1973.

Yamaji, A., Geology of Atsumi area and early Miocene rifting in the Uetsu district, northeast Japan, Mem. Geol. Soc. Japan, 32, 305-320, 1989.

Yamaji, A., Rapid inter-arc rifting in Miocene northeast Japan, Tectonics, 9, 365-378, 1990

Yamazaki, T., Paleomagnetism of Miocene sedimentary rocks around Matsushima Bay, Northeast Japan and its implication for the time of rotation of Northeast Japan, J. Geomag. Geoelectr., 41, 6, 533-548, 1989.

Zijderveld, J. D. A., A. C. demagnetization of rocks: Analysis of results, in Methods in Paleomagnetism, pp. 254-286, Elsevier, Amsterdam, 1967.

A. Yamaji (e-mail: ayamaji@ip.media.kyoto-u.ac.jp), H. Momose, and M. Torii 